\title{
Plato's Myth of Er and the Reconfiguration of Nature
}

\author{
Tae-Yeoun Keum \\ Christopher Tower Junior Research Fellow, Christ Church, University of Oxford \\ From Fall 2020: Assistant Professor, Department of Political Science, University of California, Santa Barbara \\ tae-yeoun.keum@politics.ox.ac.uk
}

\begin{abstract}
Why did Plato conclude the Republic, arguably his most celebrated work of political theory, with the Myth of Er, an obscure story of indeterminate politicaltheoretical significance? This paper advances a novel reading of the Myth of Er that attends to the common plot that it shares with two earlier narrative interludes in the Republic. It suggests that Plato constructed the myth as an account of a search, akin to the sorting of potential philosopher-kings that underwrites the kallipolis' educational curriculum, for natures that have successfully absorbed the cumulative effects of their philosophical upbringing. The model of nature presented in the myth, in turn, helps us approach the category of nature as a working concept: we can recognize contexts in which it is useful to assume in otherwise complex and fluid individuals a fixed, indelible nature, while granting that our sense of what that consists in is subject to revision.
\end{abstract}

\section{Keywords: Plato, Republic, nature, education, Myth of Er, political imagination, concept}

\footnotetext{
Acknowledgements

I have been thinking about the texts and themes in this paper for several years. I am indebted to the conversations I've had in that time with many generous individuals, including Rachel Barney, Aaron Garrett, Kinch Hoekstra, Matthew Kozlark, Jonathan Lear, and Malcolm Schofield. For comments and encouragement on earlier drafts, I am especially grateful to Jacob Abolafia, Adriana Alfaro, Danielle Allen, Robert Balling, Jonathan Bruno, Marianne Bauer, Matthew Landauer, Derin McLeod, Joe Muller, Oded Na'aman, Jon Templeman, Nancy Rosenblum, John Zumbrunnen, and audiences at the Harvard Political Theory Workshop, the Harvard Safra Center Graduate Workshop, the 2014 Meeting of the Northeastern Political Science Association and the 2018 Meeting of the American Political Science Association. I am additionally grateful to Leigh Jenco and three anonymous reviewers, whose incisive comments improved the paper significantly.
} 
Using the language of nature to evaluate particular human traits, behaviors, or differences is an especially divisive - yet enduring - fixture of modern political discourse. In recent decades, acrimonious battles over what is and is not natural have been fought in disputes as wide-ranging and contentious as those on natural aptitude in education (Daniels 1974; Lemann 2000; Staub 2018), LGBTQ rights (Jaffa 1988; 1994, 256, 263, 383; Macedo 1995, 265-267), the meaning of gender and gender identity (Beauvoir 2011; Butler 1990; Jaggar 1983; Pew Research Center 2017), to the ethics of bioengineering (Fukuyama 2002; Habermas 2003; Kass 1998). Political claims to naturalness and unnaturalness in such debates are distinctively polarizing because they are rarely neutral observations: to paraphrase the feminist philosopher Nancy Holmstrom $(1998,280)$, claims about human nature are not merely descriptive, but carry powerful normative implications. The fraught character of such claims, in turn, has increasingly given way to the suspicion that nature is an unhelpful, if not misleading or dangerous, conceptual category in terms of which to think about people in political contexts (Dupré 2011; Hull 1986; Lewens 2012). Allegations about the naturalness of human attributes are prone to imprecision (Laland and Brown 2018), routinely drawn from faulty assumptions, and have a particularly unsavory history of supplying ideological justification for oppressive movements and regimes (Haslam 2006; Jaggar 1983; Lewontin, Rose, and Kamin 1984) - echoes of which are newly reverberating across the extremist rhetoric of the rising "global right" (Datta 2018).

But if nature is a specious conceptual category on which to base our understandings of persons, it is one that we have difficulty leaving behind. Decades of scientific and philosophical work aimed at dismantling the popular dichotomy between nature and nurture has perennially met a backlash from critics alleging that these efforts have gone too far, lapsing into denialism 
about the role of innate factors in shaping who we are (Pinker 2002). This impasse, commentators often observe, comes less from any real disagreement on whether humans are exclusively the products of influences that are either wholly inherent or wholly environmental, and more reflects the conceptual work remaining to be done in developing a satisfying alternative framework (Toren 2018, 170; Kronfeldner 2018).

Today, much of the controversy surrounding the concept of nature tends to center on biology and genetics, but it is important to recognize that these contemporary discussions are part of a broader effort to grapple with this more normative task - an ontological undertaking on which recent political theory has often been conspicuously silent (Bagg 2018, 3 and 20n5; Rawls $2005,18,86-88,481-82$; White 2000,17$)$. To begin, that project requires us to grasp the extent to which deeply ingrained world views, intuitions, and linguistic practices continue to be structured by the idea that humans are importantly defined in some capacity by a set of essential and invariant traits, which accompany them throughout their lives and ground their dispositions (Keller 2010). Recent defenders of the concept of nature have therefore argued instead for its reconceptualization: disassociating it from the deterministic connotations that have traditionally loomed over it; better accounting for the plurality of human experiences and sources of identity; and reflecting the fluid interaction of internal and external influences on human development (Bagg 2018; Frost 2016; Kronfeldner, Roughley, and Toepfer 2014; Kronfeldner 2018).

The ongoing search for more nuanced frameworks for thinking about the natures of persons may strike us as a modern conundrum - say, of catching up to advances in scientific understanding. But it is more longstanding than political theorists often realize, and more deeply rooted in the traditional canons of political thought. This article argues that the project of developing a dynamic conception of individual nature importantly frames Plato's political 
thought, and in particular lies at the center of the Republic's famously enigmatic conclusion, the Myth of Er. It shows that the Myth of Er articulates a constitutive model of the relationship between an individual's nature and her cultural upbringing, and that recovering this model can constructively supplement contemporary efforts at reconceptualizing the category of nature.

The Myth of Er, a baffling passage concluding what is likely Plato's most widely-read work of political theory today, poses a perennial puzzle in the interpretation of Plato's Republic. It is a myth told by Socrates, the Republic's central protagonist and narrator, about what awaits souls in the afterlife before reincarnation: first, they are judged for the lives they had led, and made to embark on a thousand-year journey either rewarding them for their virtues or punishing them for their vices; then, the souls are given the opportunity to choose the patterns of their subsequent lives.

Why Plato chose to end the Republic this way has long been an open question, but a novel interpretation of the myth allows us to read it as an account of a search, akin to the sorting of potential philosopher-kings that underwrites the Republic's educational curriculum, for natures that have successfully internalized the cumulative effects of their philosophical upbringing. Advanced in Plato's account is a model of nature that takes individuals to possess a core essence that forms a meaningful base for their identities, but which is simultaneously capable of absorbing influences that are external to it. Importantly, this model offers an attractive vision of what it might mean to approach the category of nature as a working concept: it recognizes contexts in which it might make practical sense to assume in otherwise complex and fluid individuals a fixed, indelible nature, but it grants that our sense of what that consists in is subject to revision. 
The argument proceeds in four parts. I begin by reconstructing the interpretive challenge that the Myth of Er poses for scholarship on Plato's political theory, and I present a case for reading it as an extended treatment of the themes at the center of two earlier narrative moments in the Republic: the Myth of Metals and the Allegory of the Cave. I subsequently offer a renewed look at the two earlier narratives, tracking how Plato uses the motifs of dreaming underground and waking up above ground in order to assert a revised conception of the natures of individuals after they have undergone a cycle of education and testing. Finally, I extend these lessons to the Myth of Er, and show that its own waking-up story allows us to read it as a systematic account of an education and a test in cosmic justice. The myth presents an idealized model of nature as a composite of its previous working concepts and the influence of this final stage of education. In so doing, it concludes a protracted inquiry exploring the possibility that thick, orienting concepts like that of nature can be reworked and reimagined without losing their normative power.

The Interpretive Challenge of the Myth of Er

The political lessons of the Myth of Er have been ambiguous at best throughout its reception. Because the Republic is Plato's most celebrated work of political theory, and a staple of political theory curricula today, the obscurity of its conclusion can be all the more 
dissatisfying: the Myth of Er was once famously appraised as "a lame and messy ending" to "a powerful and otherwise impressively unified book" (Annas 1981, 353).1

For readers committed to the political-theoretical significance of the Republic, the Myth of Er presents a serious interpretive challenge that remains to be met. Many landmark studies evade the issue by either ignoring the myth (Kraut ed. 1997; Murphy 1951; Santas 2010; Schofield 2006), or granting it only a cursory treatment (Bloom 1968, 435-36; Cross and Woozley 1964, 288; Ferrari 2005, 32; Reeve 1988, 262-63; Sayers 1999, 161-63; Strauss 1964, 137-38). Those that endeavor to glean a political-theoretical lesson from the Myth of Er rightly present it as an extension of the philosophical defense of justice spanning the broader arc of the Republic (e.g. Adam ed. 1902, 456-57; Ferrari 2009; Johnson 1999; Reeve 1988). Political theorists working from this framework often read the myth as an affirmation of individual choice and agency against moral luck (Allen 2013, 76; Bobonich 2002, 56-58; Dorter 2003; McCoy 2012; Zuckert 2009, 381).

The problem, however, is that the myth does not consistently bear out such readings, with only select, momentary passages in the myth supporting them, and much of its rich, baffling detail left unaccounted for. As Julia Annas (1981, 349-353) pointed out in her famous complaint, the lessons that readers typically draw from the myth are more often than not undermined by what actually happens in it (see also Annas 1982, 130-34; Halliwell 2007, 445, 458-65; Roochnik 2003, 121-131).

The content of the Myth of Er is sufficiently convoluted that readers can find themselves divided about whether it supports or subverts the Republic's central argument: the defense of

\footnotetext{
1 While Annas $(1982,141$ 25) has subsequently withdrawn these remarks, the reasons she gave for them continue to resonate with readers of the Republic, and her concerns regarding the consistency of the Myth of Er with the rest of the book remain a question that has yet to be settled definitively (Johnson 1999).
} 
justice as a good unconditionally worthy of pursuit, and which can be defined as a kind of constitutional harmony governing the makeup of both the just soul and the famous ideal city of the kallipolis. The influential line of thought favoring the subversive interpretation belongs to the legacy of Leo Strauss's (1964) reading of the Republic, which famously found certain particular moments in the book so plainly ridiculous as to expose - and serve as an ironic comment on - the impracticability of the entire project. Strauss's portrait of a Plato trading in paradox and irony opens up ways of approaching the Myth of Er in those terms: its elaborate details may have been constructed to subvert the surface claims in the Republic's account of justice, shedding light instead on the impossibly stringent character of its moral prescriptions (Rosen 2005, 387-88), or on the inability of individual moral agents to overcome the elements of chance and contingency governing the cosmos (Benardete 1989, 225-229).

On the other hand, interpretations that take the myth to support the Republic's broader account of justice face another problem: if they are correct, the concluding myth becomes a redundant reiteration of the preceding lessons, and an unnecessarily confusing one at that (Bloom 1968,435 ; Nussbaum 1986, 130). One way of going around the issue is to suggest that the myth is not necessarily intended for the same audience as that of the philosophical arguments, but is rather a cruder form of rhetoric designed to persuade non-philosophers of the advantages of justice (Bloom 1968, 436; see also Arendt 2006, 108; Brisson 1998, 11). The countervailing solution is to embrace the myth's strangeness as an instance of what Elizabeth Markovits (2008, 151-59) calls a "summoner," or call to judgment. The Myth of Er, on this view, is deliberately disorienting or dissatisfying, and these unsettling emotions can jolt Plato's readers into practicing philosophical virtues celebrated in the Republic, like thinking critically for oneself (Seery 1988), breaking away from consequentialist guides to moral action (Annas 1982), or resisting epistemic 
hubris (Lear 2006, 38-42) and otherwise being cognizant of the limits and contexts proper to our theoretical models (Roochnik 2003, 121-131).

Political theorists have good reason to be troubled by the wide disagreement on how to interpret the pages that have the final word on what is arguably Plato's most important work of political theory. But this impasse is all the more remarkable because the range of available readings appears to suggest that it may not be possible to take the myth's convoluted details seriously without having to presume, to some extent, a distance between what Plato wrote and what he meant. This suggestion, in turn, provides a telling window into an improbably detached conception of the philosopher's relationship to society that informs several orthodox understandings of Plato's political theory and its legacy. Reproduced in the interpretations that treat the myth, alternately, as subversive commentary or as rhetoric for non-philosophers, is the familiar portrait of an elite Plato, who cautions philosophers to direct their intended messages to a separate philosophical readership apart from the ordinary agents of politics, or to make use of rhetorical resources external to philosophy in order to convince audiences lacking the capacity to reach the same conclusions through philosophical means alone. A rather different form of that detachment prevails even in readings that take the myth's function to be an invitation to philosophical judgment: echoing a prominent picture of Plato as an advocate of "Socratic citizenship" (e.g. Villa 2001), they assign to philosophers the task of provoking readers into thinking critically for themselves, much like a Socratic gadfly stinging awake the drowsy horse of Athenian society.

In the pages that follow, I show that an alternative framework for making sense of the Myth of Er is yet possible. This is an approach that allows us to take the myth's complex details at face value without assuming a hidden agenda behind them; and it is consequently one that 
encourages us to believe that Plato's relationship to his readers was more consistently earnest than it was patronizing.

I argue that Plato chose to end the Republic with the Myth of Er partly in order to extend an account, launched in the Myth of Metals and continued in the Allegory of the Cave, of the curriculum of education and testing administered to the kallipolis' citizens. My reading grows out of a literary observation. The Myth of Er shares a striking set of similarities - which tends to go unremarked by commentators - with two other narrative interludes placed at critical junctures in the Republic. First, its framing echoes the plot structure of the Myth of Metals and the Allegory of the Cave, both of which recount experiences that are described in terms of being delivered out of a subterranean place, during sleep, into a different world above and waking up there. Second, these stories of dreaming and waking are, in each case, deployed to offer a redescription of the natures of its subjects following a transformative event. In the Myth of Metals and the Allegory of the Cave, these transformations concern the potential effects of education on one's nature: how the citizens of the kallipolis are to be sorted after a basic training in music and gymnastics; the radical epistemic conversion experienced by a student of dialectic. In the Myth of Er, on the other hand, Er wakes up just as his fellow travelers are reincarnated into new natures, which are heavily determined by the patterns of lives they have selected at the end of their eschatological journey.

The preoccupation with individual nature in the earlier two stories about waking up above ground, I believe, can help illuminate its treatment in the third. The Myth of Metals and the Allegory of the Cave occur at two pivotal moments in the education and testing of the kallipolis' rulers, when the pool of prospective philosopher-guardians is purged of its less promising candidates. When we take the periodic recurrence of the plot common to these three 
stories and the periodic sorting of the city's leaders to be related, the Myth of Er also reads as an account of an analogous process of education and testing: in this case, of the search for natures on whom the cumulative effects of their philosophical educations have successfully taken hold.

Plato's investment in interrogating the relationship between philosophical education and philosophical natures suggests, in turn, that he did not solely think of philosophers as detached observers and critics of society, but that he also theorized a process of socialization during which they shared in, and were themselves shaped by, the cultural mores ingrained in the environments in which they were brought up. Philosophers, for Plato, did not sprout from nowhere, but had to be formed; and what essentially set them apart from non-philosophers was not a fact of life but an open question.

Born-Again Citizens in the Myth of Metals

The Myth of Metals in Book III of the Republic - also known as the Noble Lie - is perhaps Plato's most notorious myth. The reputation owes largely to the myth's appeal to the authority of the concept of nature as a fixed standard for organizing a city: it tells a story of how a god has mixed gold into the construction of those individuals among the citizens most naturally disposed to rule, and silver, iron and bronze into the natural assistants, farmers and craftsmen, respectively. The story encourages its audience to regard these natural aptitudes as fixed - like pure metals that cannot be transformed into one another - and it enjoins societal institutions to restore citizens to their rightful places in the natural order. 
The rigid understanding of individual nature in the myth gives it the gloss of radicalism for which the Republic is so often criticized - most famously by Karl Popper $(1963,61)$, who found in this myth an "exact counterpart" of Nazi racial policy. On this understanding, the nature of an individual citizen is not only a static and inalienable disposition that delimits what she is and is not suited for, but, like race, it cannot be helped and is determined from birth. While the Myth of Metals has since remained a primary point of reference in authoritarian or otherwise anti-democratic portraits of Plato (Dombrowski 1997; Reeve 1988, 212-13; Schofield 2006, 282-309; 2009), the view that individuals are naturally born one way or another has been ascribed to the myth even by commentators who thought much more highly of Plato than Popper did (Bloom 1968, 366; Monoson 2000, 128; Santas 2010, 10, 14n26, 160; Saxonhouse 1998, 279).

A close examination of the myth's opening lines, however, reveals a more complete picture. As we shall see, the myth's appeal to the concept of nature also involves a revision in its meaning: from the kind of biologically determined essence evoked by most orthodox readings, to a property defined by the qualities that citizens possess at the end of their early upbringing. In the kallipolis, citizens are selected and sorted on the basis of personal attributes that are discerned through a test following a basic education, which are not necessarily the attributes they have at the beginning of their biological lives (Andrew 1989, 577-78, 581, 589-90; Kasimis 2016, 35; Rowett 2016, 68-9). Accordingly, the years of a preliminary education open up a modest window of social mobility for citizens who distinguish themselves in their early studies.

Crucially, the social reorganization proposed in these passages is made possible through an extraordinary conceptual intervention. If the nature of an individual is a disposition fixed from birth, the myth explains how citizens are to be sorted on its basis by telling a story that 
reconceptualizes what it means to be born in the first place. In the myth, birth itself is

reimagined as an event that occurs not when a citizen is biologically born, but sometime after she has completed the education in music and gymnastics described in Books II and III. The myth's opening lines depict a gestation and a birth, in order to convince the newly educated citizens of the kallipolis that

the rearing and education we gave them were like dreams; they only thought they were undergoing all that was happening to them, while, in truth, at that time they were under the earth within, being fashioned and reared themselves, and their arms and other tools being crafted. When the job had been completely finished, then the earth, which is their mother, sent them up (Rep. 414d-e ).2

Until this moment, according to these lines, the citizens have not lived at all. Rather, they are told that they were in fact asleep during the years of their early education in music and gymnastics; and that they have spent these years, not in this world, but inside the womb of their mother, the earth, where both they and the distinctive markers of their occupational identities were formed. Only after this process of gestation were they released above ground, to wake into their current selves.

This has radical consequences for the concept of nature that supplies much of the myth's normative force. Here, Socrates tells the story about waking from a subterranean slumber in order to stipulate that the nature of a citizen is defined by those qualities with which she is born this time around. Whatever dispositional traits that manifest in an individual citizen at the end of 
her preliminary education, the claim goes, have to be treated as though she had possessed them all her life and will always continue to do so, regardless of whether they were in fact biologically innate, a product of this early upbringing, or - more likely - some combination of both.

Biological, especially hereditary, factors do not so much disappear from this account as they get subsumed into the proposed reconceptualization of the content of an individual's nature. The myth still assumes that members of the city's several classes will "for the most part" produce offspring like themselves, and poor observation of the city's breeding regulations is to blame for the eventual deterioration of the kallipolis (415a, 546a-547a). The point of the myth, however, is that what can be known about a citizen at the time of her biological birth is inadequate for determining her place in society (Kasimis 2016, 344; Wood and Wood 1978, 145 152). Accordingly, institutions in the city must redefine the measures of a person's natural aptitude around a more appropriate standard, and reassign, for any child whose makeup deviates from that of her parents, "the proper value to its nature" (Rep. 415c).

These proposals, in turn, also reframe our understanding of what a basic education and testing in the kallipolis does to a person. On many conventional readings of the myth, these early years simply supply the time and opportunity for the citizens' latent talents and limitations - supposedly hard-wired into their constitutions from biological birth - to begin revealing themselves. But while the myth does not rule out this possibility, it also embraces the prospect that the effects of early education might penetrate down into the inner site of those talents and limitations, and become practically indistinguishable from any such determinant of potential that might have been operating there all along. After all, Socrates designs the kallipolis' preliminary cultural curriculum around the expectation that its carefully curated content will "become established as habits and nature" in the characters of its subjects (395d). On this conception, to 
speak of an individual's nature is not to attribute to her a static, inalienable disposition determined from birth; but it is rather to recognize a more fluid amalgam of dispositional traits, blending unknown proportions of biological precondition and the influence of her early upbringing, that for all intents and purposes warrants being treated as static and inalienable from a certain age.

The Myth of Metals has thus been characterized in a number of studies as an act of political deception that seeks to "blur the distinction between nature and art and between nature and convention" (Strauss 1964, 102; see also Andrew 1989, 585). These studies rightly identify the radical innovation of the Myth of Metals as the representation of culture as nature. They share the premise, familiar to standard readings of the myth, that citizens in the kallipolis possess natures - dispositional essences that are fixed from "birth" and remain stable thereafter. But they also note that the myth makes this appeal to the concept of nature while swapping out its content. The myth takes the characters of citizens after they have been exposed to - and potentially transformed by - the city's educational programs, and transfers to these traits the authority, the normative weight and the entrenched quality of givenness that ordinarily accompany everyday notions of what is biologically innate. As Demetra Kasimis (2016) has recently pointed out, this maneuver need not be read merely through the lens of deception and cynicism. On her interpretation, the reconfiguration of nature's content in the myth is not so much intended to deceive as it is an "open secret" that Plato shared with his readers as a way of shedding new light on a topic of deeper theoretical significance - in this case, to hold up a critical mirror to contemporary Athenian practices of regulating citizenship.

As we shall see, however, the Myth of Metals is not the only place in the Republic where Socrates makes this intervention. Accordingly, we can develop a coherent account of the central 
narrative interludes in the Republic building on the insight, shared with Kasimis (2016), that the treatment of the concept of nature in the Myth of Metals invites special theoretical interest from Plato's readers. But rather than take these passages as reflective commentary on specific political institutions in Plato's Athens, this reading suggests that they are primarily designed to set up a sequence of working concepts of nature that is immediately internal to the text of the Republic. Approached this way, the Myth of Metals is somewhat less a story about the institutionalization of class hierarchy, and more the initial articulation of an alternative framework for conceptualizing individual natures in the kallipolis.3 A person's nature, on the framework suggested in the myth, is best understood as some combination of biological predisposition and early upbringing, where the respective contribution of each is unknown and irrelevant. As we shall see, this formulation is also provisional, and it will be revisited and updated at subsequent stages in the curriculum of education and testing described in the Republic.

It bears noting that this is a framework that presupposes the natures of individuals to be fluid, insofar as they are open to internalizing the effect of one's education. But just as he insists on it in the Myth of Metals, Socrates'subsequent efforts to reconceptualize the natures of individuals will consistently appeal to the notion of nature as a fixed essence. This is, in fact, part of the whole point: it is by virtue of a stable understanding of their natures that the kallipolis' citizens can be sorted into their respective roles, and by virtue of such an understanding that they come to orient their views of the world and their places in it. When Socrates proposes summarily treating the attributes of persons after education as though they constituted a fixed nature, we might understand him to be asserting what Kwame Anthony 
Appiah (2017) has recently described as an "idealization": an imperfect representation that, for practical purposes, can be treated as if it were true.

Finally, this reading of the Myth of Metals does not, of course, deny that it helps to establish the infamously inegalitarian political structure of the kallipolis; whether the dispositions of future guardians are biologically innate or acquired along the way does not change the fact that they constitute a philosophical elite picked out to rule over their less philosophical counterparts. But it does change the focus of our understanding of the myth. When we shift the default paradigm for thinking about individual nature from biological determinism to the interaction of predisposition and educational effect, we also see that Plato does not present us with an account of natural-born philosophers in the conventional sense.

The Allegory of the Cave and the Habits of the Philosophers

By Book VII of the Republic, most of the original subjects of the Myth of Metals have dropped out of Socrates' investigation, which quickly settles into an account of the philosophical education reserved for the kallipolis' potential guardians. If my reading of the Myth of Metals is correct, Socrates' study of individual nature continues with this select group, not because Plato necessarily believes the natures of philosophers are structured in a fundamentally different way from those of ordinary citizens, but because the particular interest of his investigation is in the question of what a philosophical education does to the natures of its recipients. As such, philosophers are allocated a special role in the Republic, not only as the designated guardians of 
the kallipolis, but also as a case study in how further education necessitates a redescription of what Plato calls nature.

The philosophical education in question is the second phase of the kallipolis' educational curriculum. Having been educated in music and gymnastics and subsequently sorted on its basis (Rep. 521e), a select pool of potential guardians now faces a second round of selection (537d), in which they are to be educated in the abstract sciences leading up to the study of dialectic. The candidates selected through the corresponding round of tests will be the guardians entrusted to govern the city.

Socrates tells the Allegory of the Cave to his interlocutors, Glaucon and Adeimantus, as a way of representing the transformative effect that an education in dialectic will have on the characters and identities of those who have been subjected to it. But he does so by couching his account in the language of nature. If the Myth of Metals had proposed conceptualizing the natures of individual citizens in terms of the traits they possess after an education in music in gymnastics, the Allegory of the Cave also tells a story of an awakening in order to make an analogous claim with respect to the traits that would-be philosophers are left with at the end of this higher, more sophisticated kind of education.

Here, Socrates paints a vivid image of a prisoner who, having dwelt in an underground cave all his life, is forced to scale the path to the world above, where he opens his eyes to the light of the sun for the first time. The experience is likened to the process of opening one's eyes to knowledge: a person informed by opinion but not knowledge may be said to be merely "taken in by dreams and slumbering out of his present life," so that he is at no point ever awake: "before waking up here he goes to Hades and falls finally asleep there" (515a, 534c; see also 521c). It takes a wakeful mind to see past the illusions of the things people tend to believe, and Socrates 
tells us that the politics of the kallipolis must amount to rule "in a state of waking, not in a dream as the many cities nowadays are governed by men who fight over shadows with one another" (520c-d).

The recurrent motifs of dreaming and waking are a metaphor, once again, for a transformation in the working understanding of individual nature. Socrates designates the cave as an "image of our nature in its education and want of education" (514a). If the other prisoners conceive of themselves as shadows cast on the cave wall (515a), the prisoner who has escaped the cave knows himself to be most truly at home in the upper realm $(517 \mathrm{c}-\mathrm{d})$. The elements of this story, of ascending from an underground place to wake into a new reality, come together to make a powerful claim that an individual's nature has to be reconceptualized to reflect the expected outcome of a philosophical education.

The Allegory of the Cave, then, uses the same plot structure framing the Myth of Metals to make a familiar assertion about the content of individual natures, at an analogous juncture of selection in Socrates' description of the kallipolis' educational curriculum. How did Plato intend for his readers to understand the relationship between these parallel assertions? One temptation is to regard the claims of the Allegory of the Cave as conclusively overriding any pronouncements made about individual natures in the earlier myth. We might take the Allegory of the Cave at its word, and simply accept that the natures of the kallipolis' philosopherguardians consist - and have in fact always consisted in - those attributes that a dialectical education has brought out in them, no matter what the candidates themselves were told in a placeholder myth they heard when they were much younger. A guardian of the kallipolis trained in dialectic, for instance, would be brought up to realize a potential for philosophy that she had carried within her all her life - a fixed essence, like the blueprint of an oak contained in an acorn 
- and she would in turn be able to look back with critical distance on a time when she was told her nature consisted in musical and gymnastic excellence. From this enlightened vantage point, that earlier understanding might now seem to her to have been nothing more than a useful fiction that had helped prepared her along the path to her true calling.

It is in this vein that Jonathan Lear $(2006,32)$, in his pathbreaking study of the Republic's allegories and myths, suggests that the Allegory of the Cave functions much like a delayed punchline to a joke set up much earlier in the "proto-philosophical" Myth of Metals. The Allegory of the Cave, on his account, is a "repetition and re-creation" of the Myth of Metals to the extent that both stories work by dismissing the totality of what their respective audiences know about reality, and in so doing, planting in them the seeds of the unsettling thought that what seems to be real in the world may not be all there is. Only when the potential guardians of the kallipolis encounter the Forms through a higher education in dialectic will they have an answer to the dissatisfaction they experienced when they first heard the Myth of Metals as children, and they in turn will be in a position see what that myth was an allegory for (34-37).

Indeed when we take the Allegory of the Cave as a conclusive statement on the content of the guardians' natures - to which the claims of the Myth of Metals had merely been a temporary prelude - we seem to gain a richer insight into a point of disanalogy between the two stories. In the Myth of Metals, the citizens' experience of their preliminary education had been likened to a dream; whereas in the Allegory of the Cave, it is only the condition prior to education that is represented as a dream or a state of diminished reality, and the process of being educated in dialectic is portrayed as a slow and painful awakening. It might make sense to represent a dialectical education differently because it trains its students in a fundamentally different way of thinking from what their earlier education had required of them. If gymnastics and music had 
educated citizens "through habits ... not knowledge" (Rep. 522a), dialectic allows its practitioner to partake in those habits without losing critical perspective, just as the freed prisoner ought to be able to see both in the light of the upper realm as well as in the darkness of the cave (520b-c). If the Myth of Metals depicts the citizens' experiences prior to their preliminary education as an old reality that is permanently lost, like a dream one cannot return to, the Allegory of the Cave presents dialectic as an art that equips its students to traverse dream and reality precisely because they can distinguish between those realms.

Yet, the structural similarity between the two stories also complicates this picture. Unlike the Myth of Metals, the Allegory of the Cave is directed to an audience - Glaucon and Adeimantus, and through them, Plato's readers - that has heard this kind of story before. To a reader made familiar with the structure of the Allegory of the Cave through the Myth of Metals, the seeming conclusiveness of the dialectical awakening depicted in it is undercut by the very fact that it deposes an analogous awakening from a previous myth along the way. If the Allegory of the Cave seeks to draw a sharp distinction between a discriminating education in knowledge and a blind education in habits, the same story, by virtue of what it shares with the Myth of Metals, also points to their fundamental similarity. At the end of the day, dialectic remains a form of education that seeks to make knowledge a kind of habit: "steady and strenuous participation in arguments" - the content of dialectical training - is, for Socrates, "a gymnastic that is the antistrophe of the bodily gymnastic" (539d).

This means that the philosophical attributes of the guardians are no more prefigured into their natures than the characters of the kallipolis' citizens after their preliminary upbringing can be said to be biologically innate. Much like excellence in gymnastics and music, these philosophical qualities are better understood as the interactive product of the habits of thought 
and bearing that they have acquired from their dialectical education - which have now calcified into a kind of second nature - and their dispositions prior to this education. In particular, what is being assigned the designation of nature in the Allegory of the Cave is a modification of the formulation introduced in the Myth of Metals. Now, the working concept of a person's nature consists in an unknown amalgam of some given predisposition and the influence of a dialectical education - where the predisposition in question is in fact the combination of biological predisposition and early upbringing that had been, under a previous working concept, understood as one's nature.

The point suggested by the Allegory of the Cave is that it now suffices to conflate once again the distinction between that which was given and that which was cultivated. A character refined through an education in philosophical dialectic may not in fact be the conclusive realization of an innate essence built into one's nature, but a provisional commitment to presupposing this to be the case helps to orient the way philosophers in the kallipolis must understand themselves and their pursuits.

The Myth of Er as an Account of the Education and Testing of Natures

As we have seen, the kallipolis' program for sorting its citizens on the basis of their natures, culminating in the selection of its rulers, had operated on a sequence of working concepts of nature. At each juncture of selection, the working understanding of the content of one's nature was pegged to the attributes found in individuals after a course of education and 
testing. This meant that, in both the Myth of Metals and the Allegory of the Cave, what took on the designation of an individual's nature was a conflation of some pre-given disposition - that which had hitherto passed for nature - and the influence of the latest round of education.

The recurrence of the waking-up story in the Myth of Er suggests that there is yet one more stage in this sequence that has yet to be accounted for. Like the Myth of Metals and the Allegory of the Cave before it, the Myth of Er is structured around an awakening from a dream and a rebirth out of the earth. Its hero-messenger, Er, is killed in a battle but then comes back to life to tell the story of what he saw in the other realm, as though he had merely slept through the ordeal and had "recovered his sight and saw that it was morning and he was lying on the pyre." The journey from the afterworld back to the world of the living is an ascent, which Er travels with the souls sent to be reincarnated as they are carried "up to their birth" (Rep. 621b). The souls in the myth face a choice concerning the lives into which they are to be reborn when they next open their eyes: the "ordering of the soul" changes as it makes its way through the life it chooses, and the choice accordingly entails "looking off toward the nature of the soul" (618b-d; see also 611e-612a).

When we attend to the common plot that the Myth of Er shares with the earlier two narratives, we are better positioned to appreciate its function. In the remaining pages, I show that the myth represents Plato's latest effort to redescribe the natures of individuals after they have been subjected to a new form of education. Building on the framework developed in the earlier narratives, the Myth of Er asserts an idealization of the nature of an individual soul, as the composite of a pre-given disposition - a character that has been shaped by the education of one's life - and the influence of a final education administered in the afterlife. The content of the myth, accordingly, can be read as an account of that education and its corresponding test. 


\section{The Thousand-Year Journey: An Education in Cosmic Justice}

The first half of the Myth of Er describes the journeys of the souls in the afterlife; a report of how they choose the patterns of their next lives makes up the second. When the myth is read on its own, the souls' journeys appear to be primarily concerned with retribution for justices and injustices committed in the previous life - and this, in turn, is what makes the myth sit so oddly against the preceding endeavor, spanning most of the Republic, to defend justice as desirable in and of itself (Annas 1981, 349-353; 1982, 130-34; Halliwell 2007, 445, 458-65). On this reading, the second half of the myth might follow from the first because punishments and rewards in the afterlife act to clear away the unfinished work of worldly justice: only when these moral debts are paid do the souls have a clean ledger from which to begin their next lives (Lear 2006, 39).

When the myth, by contrast, is read through the framework of education and testing suggested by the plot it shares with the Myth of Metals and the Allegory of Cave, it becomes clear that what transpires in the eschatological journeys has a more direct bearing on how the souls select the patterns of their next lives. In particular, when those journeys are taken to constitute an education that prepares its subjects for that choice, the convoluted setting of the myth betrays a much more coherent organizing structure than commonly recognized.

The journeys of the souls begin at a "certain demonic place" with two openings in the ground and two more in the heaven above (Rep. 614c; see also Adam ed. 1902, 435; Halliwell ed. 1988, 174). There, they are judged, and their judgments are attached to them as signs, as they go their separate ways: the just through one of the heavenly openings toward a path full of 
pleasures and rewards, and the unjust through an opening in the ground to a path full of terrors and punishments. Curiously, the journeys loop back, a thousand years later, to this demonic place of judgment. Two groups of souls, returning from their separate journeys through the second pair of openings in the heaven and the earth, reunite to tell each other about what they had seen on their respective paths. They go together to a meadow, where their numerous stories are devoured eagerly. Then they travel to a certain vantage point from which they behold the Spindle of Necessity that holds the cosmos together. Finally, they are taken to Necessity's daughter, Lachesis, where they begin the process of choosing the patterns of their next lives.

A purely retributive account of the myth might dismiss the careful construction of these details as gratuitous, and at best an instance of fanciful scene-setting (Benardete 1989, 226). Accordingly, commentators tend to refrain from ascribing philosophical purpose to these elements of the myth. If, for instance, the point of the journey thus far is solely about retribution for the ills and merits of one's life, it is difficult to see why some of its features are specifically set up the way they are: why and for whom the souls are made to carry signs of their judgment; why their thousand-year journeys must circuit back to the place where they had been judged; or why the myth emphasizes, to the extent that it does, the exchange of information that takes place between the souls who have completed their respective journeys.

But when the Myth of Er is considered in light of the educational project of the Republic, the oddly elaborate program set out for the souls in the afterlife begins to make more sense. The convergence of the souls' journeys at the place of judgment, the signs they are made to carry from and back to this place with the strange geography, and the vibrant exchange of stories about each journey, can all be read as contributing pieces to a systematic education in the rewards of justice, and in its function as the greater organizing principle of a harmonious universe (see 
Baracchi 2002, 187, 194 and 219). This education, in particular, is one that compels its subjects to exercise putting together, alongside their own, the vast multiplicity of perspectives and experiences represented along the journey.

As a consequence of both the judgments passed on them and the stages of the journey they occupy, souls have differently limited knowledge of how retribution works in the afterlife. Souls who traveled the heavenly path, for instance, have no experience of the underground path (Benardete 1989, 227), and the souls yet awaiting judgment do not even know which of the paths will be theirs. But their convergence in the demonic place, where each thousand-year journey begins and ends, also permits them to access an abundance of information about experiences beyond their own (see TABLE 1). When, for example, souls return from their journeys, presumably still carrying their telltale signs - appearing "full of dirt and dust" if they had been judged unjust, and "pure from heaven" if they had been just (Rep. 614d-e) - they are seen, and their stories of terror or pleasure eagerly devoured, not only by other returning souls but by those newly arrived souls, yet to depart on their own thousand-year journeys. 
TABLE 1.

The educational spectacle at the demonic place of judgment

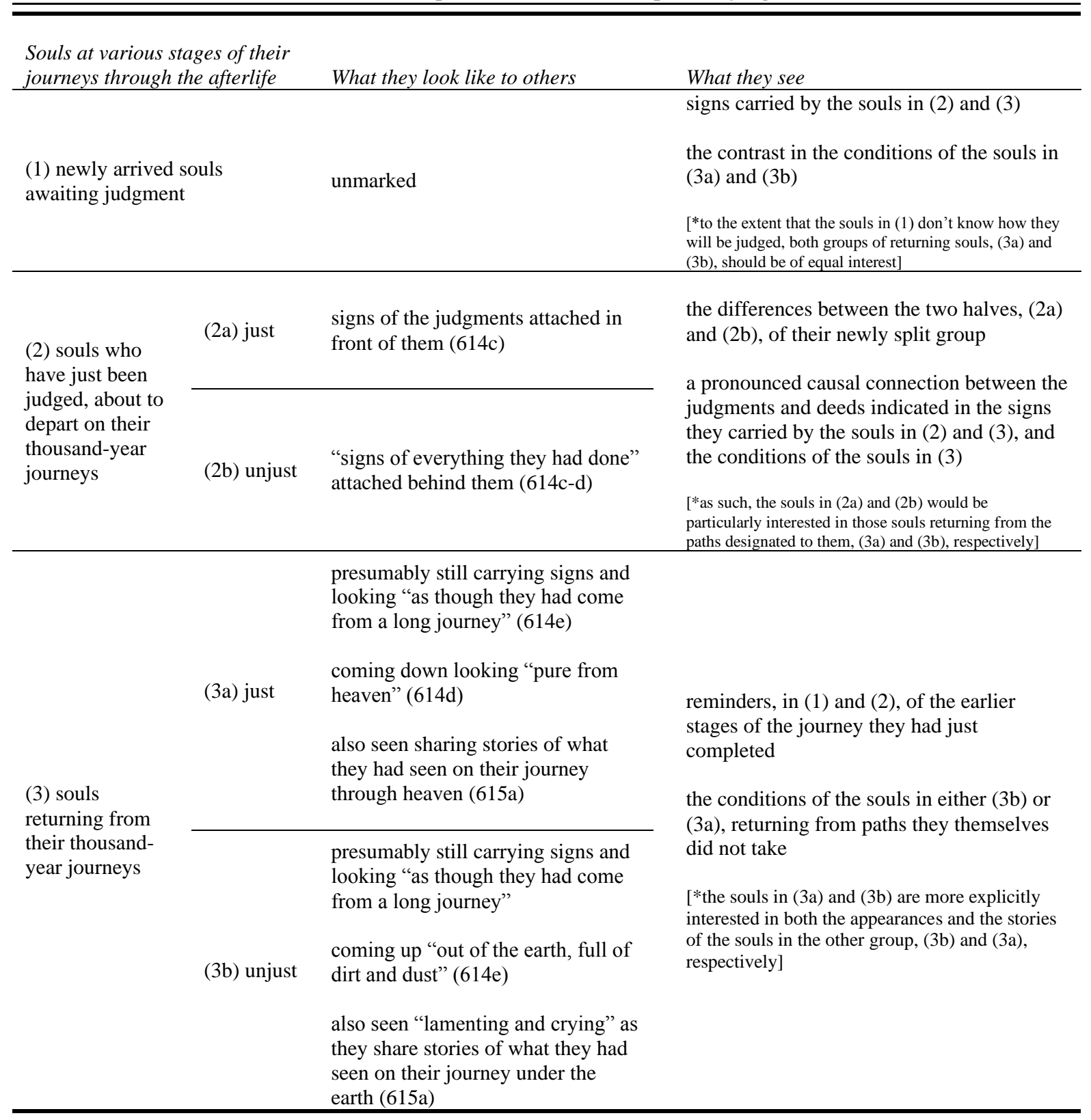

The moral lesson that it is better to be just than unjust has, of course, been told in less

roundabout ways elsewhere (Gorgias 523a-527e; Annas 1982, 125). But what sets the journey 
apart as an educational experience lies not so much in its message as in how its students arrive at it. In compelling souls to discern - by actively inquiring after journeys that were not their own what is relevant in the wealth of information at the crowded site, the convoluted geography around the demonic place of judgement mandates that each of the different paths to the same lesson is always an exercise in drawing connections: in learning how one's own experience and partial viewpoint measure against those of others, and how they might fit together schematically under an overarching principle of justice.

These are significant qualities to emphasize in this stage of the souls' journeys, because it constitutes part of a more comprehensive education in the meaning of justice that is designed to gradually expand one's outlook from the immediate and personal to the abstract and global. The exercises at the demonic place of judgment prepare their subjects, at the end of their thousandyear journeys, for a vision of the coherent universe held together by the Spindle of Necessity. Along the arc of that journey, the perspective that its pilgrims have on the world of the afterlife expands progressively: from the limited gaze they have on their own paths of retribution, to the exchange of information that occurs back at the place of judgment, and to the view of the structure of the universe. Even the passage to the Spindle is approached gradually; the souls at first see it as a column of light, and the intricate stem and nested whorls of the Spindle do not come into visibility until the following day, when the souls move closer (Rep. 616b-c).

For each soul making this journey, these shifts in perspective correspond to shifts in the meaning of justice. The souls' journeys track a lesson in the unity of cosmic justice as experienced from vantage points that gradually progress from the subjective to the objective: what is at first the retribution for the deeds committed in one's own life develops into a comprehensive system of retribution for all souls in the afterlife, until justice finally corresponds 
to the harmony of the whole cosmos (see TABLE 2). Souls in the Myth of Er, then, undergo what amounts to an immersive education in cosmic justice before they are sent to choose the pattern of their subsequent lives.

TABLE 2.

The progression of the meaning of justice in the eschatological journey

\begin{tabular}{|c|c|c|}
\hline Location in journey & Quality of perspective & Meaning of justice \\
\hline judgment & more subjective & $\begin{array}{l}\text { the name given to my deeds in life (or, if I am } \\
\text { judged unjust, its opposite) }\end{array}$ \\
\hline retributive thousand-year journey & & $\begin{array}{l}\text { retribution for my own deeds, which is an experience } \\
\text { I have in common with others on my journey }\end{array}$ \\
\hline $\begin{array}{l}\text { return to demonic place of judgment and } \\
\text { the neighboring meadow }\end{array}$ & & $\begin{array}{l}\text { the logic that everyone receives the appropriate } \\
\text { retribution for their deeds of their lives, despite the } \\
\text { variety of both the lives they led and the journeys } \\
\text { they traveled in the afterlife }\end{array}$ \\
\hline gazing upon the Spindle of Necessity & more objective & $\begin{array}{l}\text { the harmonious principle holding together the } \\
\text { cosmos }\end{array}$ \\
\hline
\end{tabular}

\section{The Choice of the Next Life: The Test of the Educated Soul}

If the first half of the Myth of Er illustrates a kind of education, the second half, which depicts souls choosing the patterns of the lives into which they will be reborn, can be read as the illustration of a test. Those making the choice must attend to "the nature of the soul" with special care, and their decision amounts to the ultimate test of "that study" by which a soul might be able to learn and find out who will give him the capacity and the knowledge to distinguish the good and the bad life, and so everywhere and always to choose the better from among those that are possible" (Rep. 618c-d).

Choosing well would require the capacity to resist packing one's subsequent life with superficial advantages, and to make one's calculations at the scale of the thousand-year journey following at 
the heels of a single lifetime. It would require knowing the shape of a just soul and the ability to discern it when it is embedded in lives as diverse as those belonging to all who traveled the heavenly path (Baracchi 2017, 214; McCoy 2012, 137). The intricacy of the eschatological journey leading up to this moment may be accounted for because its educative agenda prepares the souls for the choice; and the virtue of the lives that the souls choose would reflect, to some degree, how well they have absorbed the lessons of that cosmic education.

Reading these passages in terms of a test following an education may not in fact appear to depart very much from what is already assumed in extant interpretations of the myth: readers of the Republic are left with little uncertainty as to what a good choice would consist in, and it is reasonable to expect that rewards and punishments have taught the souls at least a crude lesson in how best to choose. This expectation, however, is thwarted by the ambiguity generated in how the souls in the myth end up making their choices. The souls generally give little consideration to their experiences in the afterlife when choosing the patterns of their subsequent lives (White 1979, 264-65). Rather, for many, those lessons in the rewards of virtue, much less in the harmony of the universe, appear to have been lost, and they make their decisions "according to the habituation of their former life" - a life they had more than a thousand years to forget (Rep. 620a). Even Odysseus, who arguably makes a well-considered choice of a quiet life as a private citizen, is said to be acting in reaction to the memory of his former life (620c).4 While souls who had been punished in the afterlife make more careful choices as a result of what they had suffered and witnessed, what gains are to be made in paying heed to the experiences and spectacles of just one's own thousand-year journey are inconsistent at best. Those souls who had

4 Odysseus is said to have discarded his love of honor through the memory of his "former labors" (tōn proterōn porōn), which could arguably be read as labors from punishments he had endured in the afterlife. Nevertheless, commentators remain divided on the question of whether Odysseus's choice exemplifies a philosophic one. 
instead traveled along the heavenly path are just as likely to rush their decisions: the first soul to choose, who hastens to choose the life of a tyrant to disastrous consequences, was "one of those who had come from heaven, having lived in an orderly regime in his former life, participating in virtue by habit, without philosophy" (619c-d).

These complicating details have divided commentators on the question of how the programming of the afterlife interacts with the souls' former lives to influence the quality of the choices that they make. In her landmark studies of the myth, Julia Annas $(1981,351)$ suggests that the mixed results of the souls' experiences in the afterlife negate the moral achievements and failures of their former lives, so that "the rewards of justice even in other-worldly terms will only lead to a compensating increase in injustice as a result." The resulting portrait, of a universe ultimately indifferent to individual efforts toward justice, initially brings Annas (1981) to take the Myth of Er as a crude and contradictory conclusion to the Republic, and later, in a revised reading, as an illustration of the point that justice cannot be conceived in terms of its external rewards after all (Annas 1982; see also White 1979, 265).

For many other commentators, however, both the eschatological journey and the habits of one's previous life introduce contingencies that obstruct philosophical decision-making. Given the overwhelming array of contingent factors working against the possibility of choosing philosophically, some of these readings have pursued a "this-worldly" line of interpretation that takes the difficulty of the moment of choosing - and the Myth of Er more broadly - as an allegory for the amplified importance of the choices we make in our present lives, which carry unforeseen consequences over long stretches of time (Thayer 1988, 377; McPherran 2010, 143). A more pessimistic, often Straussian reading also pits the ideal of making a philosophically informed choice against the souls' experiences in both their previous lives and in the afterlife - 
but largely on the grounds that the habits one comes to form in any such institutionalized context are intrinsically opposed to the pioneering spirit of ceaseless inquiry at the core of philosophic practice. For this reason Seth Benardete (1989, 229-229) casually identifies the first soul, who chooses a tyrant's life despite having lived in a virtuous city, as a "citizen of Socrates' best city," and an object lesson in the impossibility of "freeing oneself from habit" (see also Strauss 2014, 182; contra Bobonich 2002, 57-58, 475-76; Reeve 1988, 319n9).

A different account emerges, however, when the choice of life patterns is conceived not only as a test of the lessons of the eschatological journey, but as one such test extending a cumulative project of education and testing pursued in the kallipolis, aimed at the sorting of individuals around a working conception of their natures. On this reading, what is being tested for is not whether individual souls have simply learned the lessons of their thousand-year journeys, but whether they possess natures that have properly internalized the effects of this education. And what's more, the content of individual natures, as re-envisioned in the myth, consists only in part in the absorbed influences of the afterlife's cosmic education; the other part is a prior, pre-given disposition that has in turn taken in some of the effects of the education of one's own life. For a soul to pass the cosmic test, both these component parts of her nature would have to be up to standard.

This holistic and cumulative reading of the moment of choosing takes seriously the thought - suggested, for instance, in Benardete's (1989) remarks on the first soul to choose - that Plato intended for his readers to wonder how citizens of the kallipolis would fare in the scenes described in the Myth of Er, but does not give up on the possibilities of education in light of what happens in the myth. Instead, it envisions a way for the effects of education both in earthly existence and in the program of the afterlife to be aligned constructively in the natures of 
individual souls, in spite of results that overwhelmingly fall short of that ideal. Precisely because the educational curriculum of the kallipolis is structured around the vetting of natures through increasingly rigorous tests, it should be unsurprising that so many of the souls in the myth including those who have been brought up in virtuous cities - choose without consistent regard for this final stage of their education. This means that the large-scale attrition depicted in the myth does not so much invalidate the test as it radically raises the bar for the qualities for which the souls are tested. There is reason to suppose that not every guardian who has passed the test at the end of his or her dialectical education would be able to meet the new standards set in the Myth of Er; rather, the hazards that await even the soul from a virtuous city can be understood as part of a test akin to those administered in the kallipolis itself.

Crucially, reconceptualizing the moment of choosing around that standard also entails resisting the opposition between habit and philosophy presumed in some of the more pessimistic readings of the myth. It shows, rather, how this choice might work to identify those natures on which the educational apparatuses of one's city and those of the afterlife have achieved a combined effect of a particular kind, whereby habituation in the institutions of a virtuous city serves as a foundation, rather than a liability, for higher levels of education and testing. The habits that a citizen acquires from being steeped in the educational curriculum of a just city can, as in the case of the first soul to choose, combine poorly with one's experiences in the afterlife, and ultimately prove insufficient for passing the cosmic test. For a soul in possession of the correctly aligned nature, however, a lifetime of training in the forms of justice in the city and the soul would also better equip her to recognize it in the cosmos and in the myriad forms of life possible in it. 
Envisioned here, as in the earlier stories about waking up from subterranean slumbers, is an idealization of a nature in which pre-given and recently acquired features of one's self are indistinguishably fused - as though they constituted the fixed, inalienable essence of a soul who, over multiple cycles of reincarnation, consistently chooses to be reborn into lives informed by justice. This fixed image, in turn, of a superlative nature that makes it past the shifting goalposts of Plato's various tests, functions as an indispensable, constitutive ideal structuring the educational project of the Republic. If education were to play some part in the making of just souls, the layered model of nature represented in the Myth of Er suggests to us that the greater share of this work would consist, not so much in the discovery and isolation of preexisting philosophical natures as such, but in the conceptual commitments made along the way. These commitments are, at one level, necessary simplifications that presume the fixity of individual natures that may in fact be much more fluid, which helps anchor the identities of those concerned, and the institutions and norms connected to those roles, on stable and non-arbitrary foundations. At another level, such exercises in essentialism are simultaneously provisional. Though they require thinking in abstractions that belie their complexity, these commitments are periodically revisited and recalibrated, like moving targets, across the long arc of a dynamic process of forging the grounding concepts that frame the way individuals imagine their place in the world.

\section{Conclusion}


Hannah Arendt $(2006,108)$ once suggested that the Myth of Er was "a myth which Plato himself obviously neither believed nor wanted the philosophers to believe." The remark might be taken as paradigmatic of the selective reluctance, on the part of political theorists, to take Plato at his word when they read the conclusion to his most celebrated work of political theory. I have tried to offer an approach to the Myth of Er that resists the temptation to alternately dismiss or distort its content, and I have sought, in particular, to restore to our understanding of the myth both the profoundly philosophical question at its core, as well as the nuance and earnestness with which Plato went about constructing the details of its presentation.

The story of dreaming and waking that frames the Myth of Er, and which also structures the Myth of Metals and the Allegory of the Cave, suggests that there is much more continuity connecting the Republic and its final myth than readers tend to appreciate. The Myth of Metals and the Allegory of the Cave deploy this story in order to assign the designation of nature to the qualities held by individuals at different stages of the curriculum of education and testing in the kallipolis; and these same themes are taken up in the Myth of Er to extend the educational project, and to test for its aggregate effects, on a more global and long-term plane. In so doing, the myth puts forward a framework for thinking about individual nature as a working concept that warrants being treated as a fixed category, but whose content is subject to revision.

In the most recent survey of its kind on the state of contemporary scholarship on Plato, Danielle Allen (2006) divided the lay of the land into two camps: those who believed Plato held a fixed conception of human nature, and those who believed Plato thought it capable of change. If she was correct in her taxonomy, the foregoing study of the Myth of Er enriches the debate by drawing attention to the sheer extent to which Plato was himself exercised by the question of "the nature of nature" (Allen 2006, 127). 
But more importantly, it also suggests that both camps were partly right. Both of these two conflicting ideas about human nature exist in Plato's thought to some extent, and their intersection in the Myth of Er and the sequence of narratives building up to it goes to show that Plato's investment in treating individual nature as a fixed constant, on the one hand, and in periodically updating the content of that concept, on the other hand, need not be mutually exclusive. Rather, Plato likely constructed three of the Republic's most prominent narrative moments in the way that he did because he sought to draw his readers' attention, not only to the pervasive and indispensable way in which institutions and norms - including those geared toward philosophy - rely on rigid ideas about what is naturally given, but also to the capacity of these very same ideas for subsequent revision.

Plato's paradoxical insight into both the rigidity and the plasticity of our basic conceptual building blocks, in turn, encourages scholars of Plato to seek a more integrated understanding of his vision of philosophy and its relationship to the imaginative frameworks within which it operates. In particular, it points us to the need for further scholarship on how Plato might have envisioned philosophy to both shape and to be shaped by the thick constructs, tropes, and go-to metaphors that permeate culture and politics - exemplified, for instance, in Joel Schlosser's (2014) efforts to situate Plato's depiction of Socratic philosophy within the "habitus" of Athenian cultural practice; or in Allen's $(2000 ; 2013)$ own work on Plato's struggles to effect change in the symbols and conceptual systems inhabited by his audiences.

At the same time, Plato's particular engagement with the concept of nature can serve as a helpful starting point for navigating the fraught contexts in which it is invoked and weaponized today. Recourse to the categories of the natural and unnatural abound in the politics of our time as in Plato's. The language of nature in those discourses can often be blunt, rhetorical appeals, 
but often they are, at the same time, symptomatic of deeply lodged world views that do not easily accommodate change or negotiation. Plato might not have anticipated many of the contemporary controversies that have been fueled by claims about the naturalness of certain facets of ourselves, nor could he have foreseen the ways in which such controversies have sometimes sat uncomfortably with the political ideals particular to liberal democracies. He did, however, recognize both the powerful hold that the idea of a fixed nature has on the political imagination, as well as our own agency in renegotiating the contours of that which we imagine to be fixed in the order of things. His vision prescribes that we take both of these lessons seriously. If the Myth of Er captures Plato both upholding and reworking this fraught category from within, it urges political theorists not to be too quick to dismiss its intractability, but instead to seek creative ways of redrawing its boundaries. 


\section{References}

Adam, James, ed. 1902. The Republic of Plato. Cambridge: Cambridge University Press.

Allen, Danielle S. 2000. "Envisaging the Body of the Condemned: The Power of Platonic Symbols.” Classical Philology 95(2): 133-150.

—. 2006. "Platonic Quandaries: Recent Scholarship on Plato.” Annual Review of Political Science 9(1): 127-141.

. 2013. Why Plato Wrote. Malden, MA: Wiley-Blackwell.

Andrew, Edward. 1989. "Equality of Opportunity as the Noble Lie." History of Political Thought 10(4): 577-95.

Annas, Julia. 1981. An Introduction to Plato's Republic. Oxford: Oxford University Press.

—. 1982. "Plato's Myths of Judgement." Phronesis 27(2): 119-43.

Appiah, Kwame Anthony. 2017. As If: Idealization and Ideals. Cambridge, MA: Harvard University Press.

Arendt, Hannah. 2006. “What Is Authority?” In Between Past and Future, London: Penguin, 91141.

Bagg, Samuel. 2018. "Beyond the Search for the Subject: An Anti-Essentialist Ontology for Liberal Democracy." European Journal of Political Theory.

Baracchi, Claudia. 2002. Of Myth, Life, and War in Plato's Republic. Bloomington: Indiana University Press.

—. 2017. "Exile in the Flow of Time." Research in Phenomenology 47: 204-19. de Beauvoir, Simone. 2011. The Second Sex. London: Vintage.

Benardete, Seth. 1989. Socrates'Second Sailing. Chicago: University of Chicago Press. 
Bloom, Allan. 1968. “Interpretive Essay.” In The Republic of Plato, New York: Basic Books, $305-436$.

Bobonich, Christopher. 2002. Plato's Utopia Recast. Oxford: Oxford University Press.

Brisson, Luc. 1998. Plato the Myth Maker. Chicago: University of Chicago Press.

Butler, Judith. 1990. Gender Trouble. New York: Routledge.

Cross, R.C., and A.D. Woozley. 1964. Plato's Republic. London: Macmillan.

Daniels, Norman. 1974. "IQ, Heritability, and Human Nature.” PSA: Proceedings of the Biennial Meeting of the Philosophy of Science Association: 143-80.

Datta, Neil. 2018. “'Restoring the Natural Order': The Religious Extremists' Vision to Mobilize European Societies against Human Rights on Sexuality and Reproduction.” European Parliamentary Forum on Population and Development. https://www.epfweb.org/node/690.

Dombrowski, Daniel. 1997. “Plato's 'Noble' Lie.” History of Political Thought 18(4): 565-78.

Dorter, Kenneth. 2003. "Free Will, Luck, And Happiness In The Myth Of Er." Journal of Philosophical Research 28: 129-42.

Dupré, John. 2011. “What Is Natural about Human Nature?” ed. Carl Friedrich Gethmann. Deutsches Jahrbuch Philosophie 2: Lebenswelt und Wissenschaft: 160-74.

Ferrari, G.R.F. 2005. City and Soul in Plato's Republic. Chicago: University of Chicago Press.

—. 2009. "Glaucon's Reward, Philosophy's Debt.” In Plato's Myths, ed. Catalin Partenie. Cambridge: Cambridge University Press, 116-33.

Frost, Samantha. 2016. Biocultural Creatures. Durham, NC: Duke University Press.

Fukuyama, Francis. 2002. Our Posthuman Future. New York: Farrar, Straus and Giroux. Habermas, Jürgen. 2003. The Future of Human Nature. Cambridge, MA: Polity. 
Halliwell, Stephen, ed. 1988. Republic 10. Warminster: Aris \& Phillips.

—. 2007. "The Life-and-Death Journey of the Soul." In The Cambridge Companion to Plato's Republic, ed. G.R.F. Ferrari. Cambridge: Cambridge University Press, 445-73.

Haslam, Nick. 2006. "Dehumanization: An Integrative Review.” Personality and Social Psychology Review 10(3): 252-264.

Holmstrom, Nancy. 1998. "Human Nature.” In A Companion to Feminist Philosophy, eds. Alison Jaggar and Iris Marion Young. Malden, MA: Blackwell, 280-88.

Hull, David L. 1986. “On Human Nature." PSA: Proceedings of the Biennial Meeting of the Philosophy of Science Association 2: 3-13.

Jaffa, Harry. 1988. "Humanizing Certitudes and Impoverishing Doubts.” Interpretation 16: 11138.

- 1994. Original Intent and the Framers of the Constitution. Washington, DC: Regnery Gateway.

Jaggar, Alison. 1983. Feminist Politics and Human Nature. Totowa, NJ: Rowman \& Allanheld.

Johnson, Ronald R. 1999. 'Does Plato's 'Myth of Er' Contribute to the Argument of the Republic?" Philosophy \& Rhetoric 32(1): 1-13.

Kasimis, Demetra. 2016. “Plato's Open Secret.” Contemporary Political Theory 15(4): 339-357.

Kass, Leon. 1998. “The Wisdom of Repugnance.” Valparaiso University Law Review 32(2): $679-705$.

Keller, Evelyn Fox. 2010. The Mirage of a Space between Nature and Nurture. Durham, NC: Duke University Press.

Kraut, Richard, ed. 1997. Plato's Republic. Lanham, MD: Rowman \& Littlefield.

Kronfeldner, Maria. 2018. What's Left of Human Nature? Cambridge, MA: MIT Press. 
Kronfeldner, Maria, Neil Roughley, and Georg Toepfer. 2014. "Recent Work on Human Nature: Beyond Traditional Essences.” Philosophy Compass 9(9): 642-652.

Laland, Kevin, and Gillian Brown. 2018. “The Social Construction of Human Nature.” In Why We Disagree About Human Nature, eds. Elizabeth Hannon and Tim Lewens. Oxford: Oxford University Press, 127-44.

Lear, Jonathan. 2006. “Allegory and Myth in Plato’s Republic.” In The Blackwell Guide to Plato’s Republic, ed. Gerasimos Xenophon Santas. Oxford: Wiley-Blackwell, 25-43.

Lemann, Nicholas. 2000. The Big Test: The Secret History of the American Meritocracy. New York: Farrar, Straus and Giroux.

Lewens, Tim. 2012. "Human Nature: The Very Idea.” Philosophy \& Technology 25(4): 459474.

Lewontin, Richard, Steven Rose, and Leon Kamin. 1984. Not in Our Genes: Biology, Ideology, and Human Nature. New York: Pantheon.

Macedo, Stephen. 1995. "Homosexuality and the Conservative Mind." Georgetown Law Journal 84: $261-300$.

Markovits, Elizabeth. 2008. The Politics of Sincerity. University Park, PA: Pennsylvania State University Press.

McCoy, Marina. 2012. "Freedom and Responsibility in the Myth of Er.” Ideas y Valores 61(149): 125-41.

McPherran, Mark. 2010. "Virtue, Luck, and Choice at the End of the Republic." In Plato's Republic: A Critical Guide, ed. Mark McPherran. Cambridge: Cambridge University Press, 132-46. 
Monoson, S. Sara. 2000. Plato’s Democratic Entanglements. Princeton: Princeton University Press.

Murphy, Neville. 1951. The Interpretation of Plato's Republic. Oxford: Clarendon Press.

Nussbaum, Martha. 1986. The Fragility of Goodness. Cambridge: Cambridge University Press.

Pew Research Center. 2017. "On Gender Differences, No Consensus on Nature vs. Nurture.” (December 5). https://www.pewsocialtrends.org/2017/12/05/on-gender-differences-noconsensus-on-nature-vs-nurture/

Pinker, Steven. 2002. The Blank Slate: The Modern Denial of Human Nature. New York: Viking.

Plato. 1968. The Republic, trans. Allan Bloom. New York: Basic Books.

Plato. 1997. Complete Works. eds. John M. Cooper and D.S. Hutchinson. Indianapolis: Hackett. Popper, Karl. 1963. The Open Society and Its Enemies, Vol. 2: The High Tide of Prophesy. Princeton: Princeton University Press.

Rawls, John. 2005. Political Liberalism. Expanded edition. New York: Columbia University Press.

Reeve, C.D.C. 1988. Philosopher-Kings: The Argument of Plato's Republic. Princeton: Princeton University Press.

Roochnik, David. 2003. Beautiful City: The Dialectical Character of Plato's Republic. Ithaca: Cornell University Press.

Rosen, Stanley. 2005. Plato's Republic. New Haven: Yale University Press.

Rowett, Catherine. 2016. "Why the Philosopher Kings Will Believe the Noble Lie." Oxford Studies in Ancient Philosophy 50: 67-100.

Santas, Gerasimos Xenophon. 2010. Understanding Plato's Republic. Oxford: Wiley-Blackwell. 
Saxonhouse, Arlene. 1998. "Democracy, Equality, and Eidê: A Radical View from Book 8 of Plato’s Republic.” American Political Science Review 92(2): 273-83.

Sayers, Sean. 1999. Plato’s Republic. Edinburgh: Edinburgh University Press.

Schlosser, Joel. 2014. What Would Socrates Do? New York: Cambridge University Press.

Schofield, Malcolm. 2006. Plato: Political Philosophy. Oxford: Oxford University Press.

—. 2009. "Fraternité, Inégalité, La Parole de Dieu.” In Plato’s Myths, ed. Catalin Partenie. Cambridge: Cambridge University Press, 101-15.

Seery, John Evan. 1988. "Politics as Ironic Community: On the Themes of Descent and Return in Plato's Republic.” Political Theory 16(2): 229-56.

Staub, Michael E. 2018. The Mismeasure of Minds. Chapel Hill: University of North Carolina Press.

Strauss, Leo. 1964. The City and Man. Chicago: University of Chicago Press.

- 2014. On Tyranny. eds. Michael S. Roth and Victor Gourevitch. Chicago: University of Chicago Press.

Thayer, H.S. 1988. “The Myth of Er.” History of Philosophy Quarterly 5(4): 369-84.

Toren, Christina. 2018. "Human Ontogenies as Historical Processes.” In Why We Disagree About Human Nature, eds. Elizabeth Hannon and Tim Lewens. Oxford: Oxford University Press, 170-85.

Villa, Dana. 2001. Socratic Citizenship. Princeton: Princeton University Press.

White, Nicholas P. 1979. A Companion to Plato's Republic. Oxford: Basil Blackwell.

White, Stephen K. 2000. Sustaining Affirmation. Princeton: Princeton University Press.

Wood, Ellen, and Neal Wood. 1978. Class Ideology and Ancient Political Theory. Oxford: Basil Blackwell. 
Zuckert, Catherine. 2009. Plato's Philosophers. Chicago: University of Chicago Press. 